\title{
Foliar Application of Steinernema yirgalemense to Control Plano- coccus ficus: Assessing Adjuvants to Improve Efficacy
}

\author{
T. Platt ${ }^{2}$, N.F. Stokwe ${ }^{1,2}$, A.P. Malan ${ }^{2, *}$ \\ (1) ARC Infruitec-Nietvoorbij, Private Bag X5026, Stellenbosch 7599, South Africa \\ (2) Department of Conservation Ecology and Entomology, Stellenbosch University, Private Bag X1, Matieland 7602, South
Africa
}

Submitted for publication: April 2018

Accepted for publication: July 2018

Keywords: Adjuvants, entomopathogenic nematodes, Steinernema yirgalemense, Planococcus ficus, vine mealybug

\begin{abstract}
The vine mealybug (Planococcus ficus) is regarded as a key mealybug pest of grapevines in South Africa, with entomopathogenic nematodes (EPNs) being touted as a potential alternative to chemical control, although their vulnerability to above-ground environmental conditions has limited their use. In this study, tests were conducted to assess the ability of adjuvants to increase the deposition of $S$. yirgalemense on grapevine leaves. The combination of $\mathrm{Nu}-\mathrm{Film}-\mathrm{P}^{\circledR}$ and $\mathrm{Zeba}^{\circledR}$ resulted in significantly more infective juveniles (30) being deposited per $4 \mathrm{~cm}^{2}$ leaf disc than with either the control (14.8), or with $\mathrm{Nu}-\mathrm{Film}-\mathrm{P}^{\circledR}$ (23.3), although not significantly more than with Zeba ${ }^{\circledR}$ alone (29.2). The ability of $S$. yirgalemense, in conjunction with the two adjuvants, to control $P$. ficus on grapevine foliage was then assessed under controlled conditions. The application of $S$. yirgalemense with both Zeba ${ }^{\circledR}$ and $\mathrm{Nu}-\mathrm{Film}-\mathrm{P}^{\circledR}$ to $P$. ficus on leaf discs in a growth chamber resulted in $84 \%$ mortality, significantly greater than that attained by the application of $S$. yirgalemense with either $\mathrm{Zeba}^{\circledR}(47 \%)$, or water alone $(26 \%)$. Similar results were observed in a glasshouse trial, in which the combination of $S$. yirgalemense, Zeba ${ }^{\circledR}$ and Nu-Film-P ${ }^{\circledR}$ offered $\mathbf{8 8 \%}$ control of $\boldsymbol{P}$. ficus on leaf discs hung on potted vines, compared with the control that was achieved with $S$. yirgalemense with either Zeba ${ }^{\circledR}(56 \%)$ or water alone $(30 \%)$. This study demonstrates the potential of a combination of $S$. yirgalemense with adjuvants to give significant control of $P$. ficus on grapevine foliage, compared with using EPNs alone.
\end{abstract}

\section{INTRODUCTION}

South Africa is the twelfth largest producer of wine and table grapes in the world, producing $2.61 \%$ of the world's grapes in 2014 (FAO, 2016). Wine and table grape production therefore is of significant economic importance to South Africa, and especially to the Western Cape province, where the majority of wine and table grape production occurs (South African Wine Industry Information and Systems [SAWIS], 2015; South African Table Grape Industry [SATI], 2016).

The vine mealybug, Planococcus ficus (Signoret) (Hemiptera: Pseudococcidae), is a pest of grapevine found in most grape-producing regions worldwide (Ben-Dov, 1994; Walton \& Pringle, 2004). It is the predominant pest of grapevine in South Africa (Walton, 2003; Walton et al., 2004), causing damage chiefly by transmitting the grapevine leafroll-associated virus type III (GRLaV-3), which causes the rolling and discolouration of vine leaves (Bovey et al., 1980). Mealybugs also damage vines by phloem feeding, which reduces the flow of plant sap to the fruit, thereby reducing yield (Millar, 2002); and by depositing waxy residues and sooty mould-encouraging honeydew, thereby disfiguring the grapes (Geiger \& Daane, 2001).

Existing measures to control the vine mealybug on grapevines have tended to focus on chemical control, with anti-mealybug products using active ingredients such as imidacloprid, dichlorvos and methidathion (Agri-Intel, 2018). However, due to the potential for harm to nontarget organisms via direct contact, or the contamination of groundwater, as well as the potential for target insects to develop resistance, biological alternatives are often sought as a possible solution to the existing problem (Hussaini, 2002). In particular, $P$. ficus has innate defences against chemical pesticides, such as its high reproductive rate, which allows for an increase in the pace of development of its resistance to pesticides (Daane et al., 2008), while both its cryptic choice of environment (typically beneath raised grapevine bark) and the waxy filaments that it produces serve as barriers to pesticide contact, post-application (Berlinger, 1977).

*Corresponding author: E-mail address: apm@sun.ac.za

Acknowledgements: The authors would like to thank Winetech, the South African Table Grape Industry (SATGI), the Agricultural Research Council (ARC) and the Technology and Human Resources for Industry Programme (THRIP grant number: TP14062571871), for funding the project. We would also like to thank D.G. Nel, for assistance with the statistical analysis 
Entomopathogenic nematodes (EPNs) are soilbased pathogens of insects, mainly from the families Steinernematidae and Heterorhabditidae, which are widely used as biocides against the soil-based insect life stages (Campos-Herrera, 2015). EPNs encounter their prey by means of exhibiting behaviour on a continuum from stationary, 'ambushing' (which is better for active prey) to mobile, 'cruising' behaviour (which is more suited to passive and/or cryptic prey) while in a free-living infective juvenile (IJ) life stage (Lewis, 2002; Campbell et al., 2003; Griffin et al., 2005). Once they encounter prey, the IJs enter the pest insect's body cavity through the natural openings, thereby killing the insect, in conjunction with its symbiotic bacteria species, and undergoing several generations within the cavity of the insect (Griffin et al., 2005). EPNs are an attractive potential biological control agent, due to their initial virulence to the target pest, their ability to actively seek out insect pests, and their relatively low persistence within the environment (Smits, 1996; Wilson \& Gaugler, 2004). The use of EPNs to control insect pests is common and effective against soil-based insect pests (Wilson \& Gaugler, 2004).

The application of EPNs to control above-ground insect life stages is less common, mostly due to abiotic factors that affect nematode survival, particularly temperature (Grewal et al., 1994), humidity (Lello et al., 1996; De Waal et al., 2013), and ultraviolet radiation (Gaugler \& Boush, 1978). EPNs make use of any water film on the leaves in humid environments to infect their insect prey, making the EPN application more useful in tropical and/or rainy environments than in dryer ones, or at the time of day in which relative humidity is highest (Mráček, 2002).

Arthurs et al. (2004) performed a review of 136 published trials, each investigating the potential of EPNs against aboveground pests. They found that nematode efficacy depended on the target habitat, with most successful application occurring against hole-boring insect pests, followed by insects that select protected, cryptic habitats, with insect pests found in exposed habitats proving most difficult to control. Various studies have assessed the ability of EPNs to control insect pests in the laboratory, glasshouse and field, with the general trend being: the more similar a target insect's habitat is to soil (in terms of temperature, humidity and shelter from abiotic stresses such as UV exposure), the more successful EPN application will be.

One possible means of increasing EPN efficacy on foliage involves the improvement of EPN formulations by means of adjuvants, which are chemical additives that alter the physical properties of formulations. The formulation of EPN solutions with adjuvants has proven promising in their use against boring insect pests, whose bored tunnel environments are shielded from environmental stresses. Shapiro-Ilan and Cottrell (2006) assessed the efficacy of EPNs against the lesser peach tree borer, Synanthedon pictipes (Grote and Robinson), and found Steinernema carpocapsae (Weiser, 1955) Wouts, Mráček, Gerdin \& Bedding, 1982 to be the most effective EPN. Further trials tested the effects of several adjuvant compounds on the survival and efficacy of $S$. carpocapsae. Shapiro-Ilan et al. (2010) found that Barricade ${ }^{\circledR}$ fire gel improved EPN activity when applied as a post-application treatment, with further trials (Shapiro-Ilan et al., 2016) finding that the formulation of $S$. carpocapsae with Barricade ${ }^{\circledR}$ fire gel gave control equivalent to the application of chlorpyrifos.

The anti-transpirant Folicote ${ }^{\circledR}$ has been used to increase the lifespan of $S$. carpocapsae on beans, improving IJ viability from $38 \%$ to $60 \%$, at $60 \%$ RH over $6 \mathrm{~h}$ in an exposed foliage environment (Glazer, 1992). Baur et al. (1997) investigated the application of several adjuvant-nematode preparations for efficacy against the diamondback moth, Plutella xylostella (Linnaeus) (Lepidoptera: Plutellidae), and concluded that, while such preparations probably did not justify their commercial application against $P$. xylostella, the addition of adjuvants improved the persistence and efficacy of the EPNs tested. Head et al. (2004) found that the addition of either of the two surfactants, Agral ${ }^{\circledR}$ and Triton X-100 ${ }^{\circledR}$, to formulations of Steinernema feltiae (Filipjev, 1934) Wouts, Mráček, Gerdin \& Bedding, 1982 significantly increased the latter's efficacy against the foliage-dwelling life stages of the tobacco whitefly, Bemicia tabaci (Gennadius) (Homoptera: Aleryodidae), on tomato and verbena plants, with no adverse effects occurring on EPNs or in terms of host plant phytotoxicity.

The main objective of this study was to test the effect of adjuvants on the efficacy of above-ground applications of EPNs to control P. ficus on grapevine. Bioassays were performed to assess the ability of adjuvants to improve EPN deposition, and efficacy against $P$. ficus on grapevine foliage. These bioassays were performed in the growth chamber (a highly-controlled, low-variance environment) and in the glasshouse (a medium-controlled, medium-variance environment).

\section{MATERIALS AND METHODS \\ Source of nematodes}

The nematode species used in the current study, Steinernema yirgalemense Nguyen, Tesfamariam, Gozel, Gaugler \& Adams, originated from samples that were collected locally, and maintained and cultured at Stellenbosch University (Malan et al., 2011). Infective juveniles (IJs) were cultured in vivo by infecting larvae of the mealworm beetle Tenebrio molitor L. (Tenebrionidae: Coleoptera) with IJs. Dead infected mealworms were kept at $25^{\circ} \mathrm{C}$ in a petri dish lined with moist filter paper and sealed with Parafilm until IJ emergence, before being transferred to White traps (White, 1927). The IJs harvested from the White traps were transferred to vented culture flasks, where they were kept at $14^{\circ} \mathrm{C}$, in keeping with the guidelines set out by Kaya and Stock (1997). These flasks were gently agitated once a week to improve aeration. IJs for the experiment were used within one week of emergence. The experiment was repeated on a different test date, with a fresh batch of nematodes.

\section{Source of insects}

A laboratory culture of $P$. ficus was established to ensure reliable access to female individuals. The culture, which originated at the Agricultural Research Council (ARC) Infruitec-Nietvoorbij in Stellenbosch, South Africa, was propagated on butternut squash (Cucurbita moschata (Duchesne ex Lam.) Duschesne ex Poir.) in a Perspex cage under ambient conditions. The cage was vented with mesh 
netting to allow for air circulation, although it was otherwise kept sealed to prevent the escape of any mealybug nymphs. A fresh butternut was added once every three weeks to allow the individuals to migrate from the older butternut, which was then removed once rot set in. Females were removed for testing with a fine paintbrush and a pair of tweezers. Individuals were removed only if they were not currently feeding, as damage to mouthparts can impact the survivability of the insect.

\section{Adjuvant deposition}

An experiment was set up to test the efficacy of two adjuvants, Zeba $^{\circledR}$ [starch-g-poly (2-propenamideco-2-propenoic acid) potassium salt, Tongaat Hulett Starch, Germiston, South Africa] and Nu-Film-P ${ }^{\circledR}$ (poly-1-p-menthene, spreader, sticker; Hydrotech, Pretoria, South Africa), in applying S. yirgalemense to grapevine leaves. Four nematode $250 \mathrm{ml}$ suspensions were prepared, each containing $1000 \mathrm{IJs} / \mathrm{ml}$, with one containing $\mathrm{Zeba}^{\circledR}(0.3 \mathrm{~g} / \mathrm{L})$, one containing $\mathrm{Nu}$ Film- $\mathrm{P}^{\circledR}(0.6 \mathrm{ml} / \mathrm{L})$, one containing equal parts $\mathrm{Zeba}^{\circledR}$ and $\mathrm{Nu}-$ Film- $\mathrm{P}^{\circledR}$ at $0.3 \mathrm{~g} / \mathrm{L}$ and $0.6 \mathrm{ml} / \mathrm{L}$ respectively, and one with a control of IJs in water alone. The adjuvants were applied according to the recommendations on the labels.

A handheld sprayer was used to apply the abovementioned formulations to the grapevine leaves. Each suspension was applied to a green grapevine leaf (harvested no longer than 24 hours prior to use) that was suspended from a line, from a distance of $20 \mathrm{~cm}$, until runoff $(\approx 5 \mathrm{ml})$. The procedure was repeated, using five leaves per treatment. Each leaf was allowed $3 \mathrm{~min}$ post-application to allow any excess formulation to run off, after which two $4 \mathrm{~cm}^{2}$ discs were cut from each leaf, giving 10 discs per suspension. Each leaf disc was then rinsed with $\approx 5 \mathrm{ml}$ of tap water, holding the disk with a tweezer and using a wash bottle. The IJs from each disc were concentrated by settling a $10 \mathrm{ml}$ cylinder for $30 \mathrm{~min}$, after which the supernatant pipetted off and $1 \mathrm{ml}$ was transferred to the individual wells $(3 \mathrm{ml})$ of a bioassay tray (24-well, flat bottom, Nunce Cat. No. 144530, Sigma-Aldrich Pty. Ltd, Johannesburg, South Africa). The nematodes present in the rinsed water were counted and compared between treatments. The experiment was repeated on a different test date with a fresh batch of nematodes.

\section{Growth chamber bioassay}

To simulate greenhouse conditions, large plastic containers were filled with water and placed at the bottom of growth chambers to increase humidity. Grapevine leaves obtained from Welgevallen Experimental Farm were washed in a solution of water and $0.01 \%$ household bleach, rinsed thoroughly in tap water, and left to dry before use (to ensure that the leaves were free of remnants of previous unknown applications). Eight mealybugs were transferred to each of eight leaves (eight replicates, 64 insects) for each treatment. The leaves were cut to fit Petri dishes of $13 \mathrm{~cm}$ in diameter lined with moist filter paper. Treatments were water only; $S$. yirgalemense in water; $S$. yirgalemense + Zeba $^{\circledR}$ in water; and S. yirgalemense + Zeba $^{\circledR}+\mathrm{Nu}-$ Film- ${ }^{\circledR}$ in water. Zeba ${ }^{\circledR}$ and Nu-Film- $\mathrm{P}^{\circledR}$ were used in the treatments at a concentration of $0.03 \%$ and $0.06 \%$ respectively. The treatment formulations were prepared $1 \mathrm{~h}$ before each trial.
The IJs were applied to the leaves with the aid of a calibrated handheld spray applicator at a concentration of $3000 \mathrm{IJ} / \mathrm{ml}$. The leaves were left for $3 \mathrm{~min}$ after treatment to eliminate excess runoff. They were then placed in small pockets made of fine-mesh netting. The pockets were hung in the growth chamber in a complete randomised design. After $48 \mathrm{~h}$, the mealybugs were removed from the leaves and mortality was assessed. The mealybugs were then washed to remove surface nematodes, placed in Petri dishes lined with moistened filter paper, and incubated for a further $48 \mathrm{~h}$ at $25^{\circ} \mathrm{C}$ (to ensure nematode development), after which mortality by infection was confirmed by dissection. The temperature and humidity were monitored using iButtons, which were placed inside the growth chambers. The experiment was repeated on a later date with a fresh batch of nematodes.

\section{Greenhouse trial}

The leaf disc pockets, mealybugs and nematode/adjuvant solutions were prepared as for the growth chamber bioassay, with the same treatments and number of replicates per treatment. After preparation, each of the 40 pockets containing the treated mealybugs was hung on Chenin Blanc potted grapevines located in a glasshouse. The temperature $\left(22 \pm 5^{\circ} \mathrm{C}\right)$ and relative humidity $(75 \pm 8 \%)$ in the glasshouse were monitored using dataloggers. The experiment was repeated at a later date, with the results being pooled for analysis.

\section{Data analysis}

The analysis of all trial data was conducted using STATISTICA statistical analysis software version 13 (TIBCO Inc., 2017). The data were analysed using variance estimation, precision and comparison (VEPAC) and analysis of variance (ANOVA), using Bonferroni's method for the post-hoc comparison of means. Results from the adjuvant deposition were analysed using a one-way ANOVA, while for the growth chamber and greenhouse bioassays a two-way ANOVA was used. Significant differences were calculated to the $95 \%$ probability level.

\section{RESULTS}

No significant difference was recorded between the two sets of data in each bioassay, and consequently the data from the two test dates of each experiment were pooled for analysis.

\section{Adjuvant deposition}

The number of live IJs retrieved from the grapevine leaves indicate a significant difference between treatments $\left(\mathrm{F}_{(3,76)}\right.$ $=11.548, \mathrm{p}<0.01)$. The combination of Nu-Film- $\mathrm{P}^{\circledR}$ and Zeba $^{\circledR}$ was seen to result in the deposition of a significantly higher number $(\mathrm{p}=0.01)$ of IJs $\left(30.8 \pm 4 \mathrm{IJS} / 4 \mathrm{~cm}^{2}\right)$ compared to the control $\left(14.8 \pm 2 \mathrm{IJS} / 4 \mathrm{~cm}^{2}\right)$ and that of Nu-Film-P ${ }^{\circledR}$ alone $\left(23.3 \pm 2 \mathrm{IJs} / 4 \mathrm{~cm}^{2}\right)$. However, the combination of Nu-Film-P ${ }^{\circledR}$ and Zeba $^{\circledR}$ did not result in significantly more nematodes being deposited $(\mathrm{p}=0.59)$ than did the Zeba ${ }^{\circledR}$ alone (29.2 $\left.\pm 3 \mathrm{IJs} / 4 \mathrm{~cm}^{2}\right)$ (Fig. 1).

\section{Growth chamber bioassay}

The analysis of the results shows that mortality for each treatment differed significantly from all others $\left(\mathrm{F}_{(3,120)}=\right.$ 


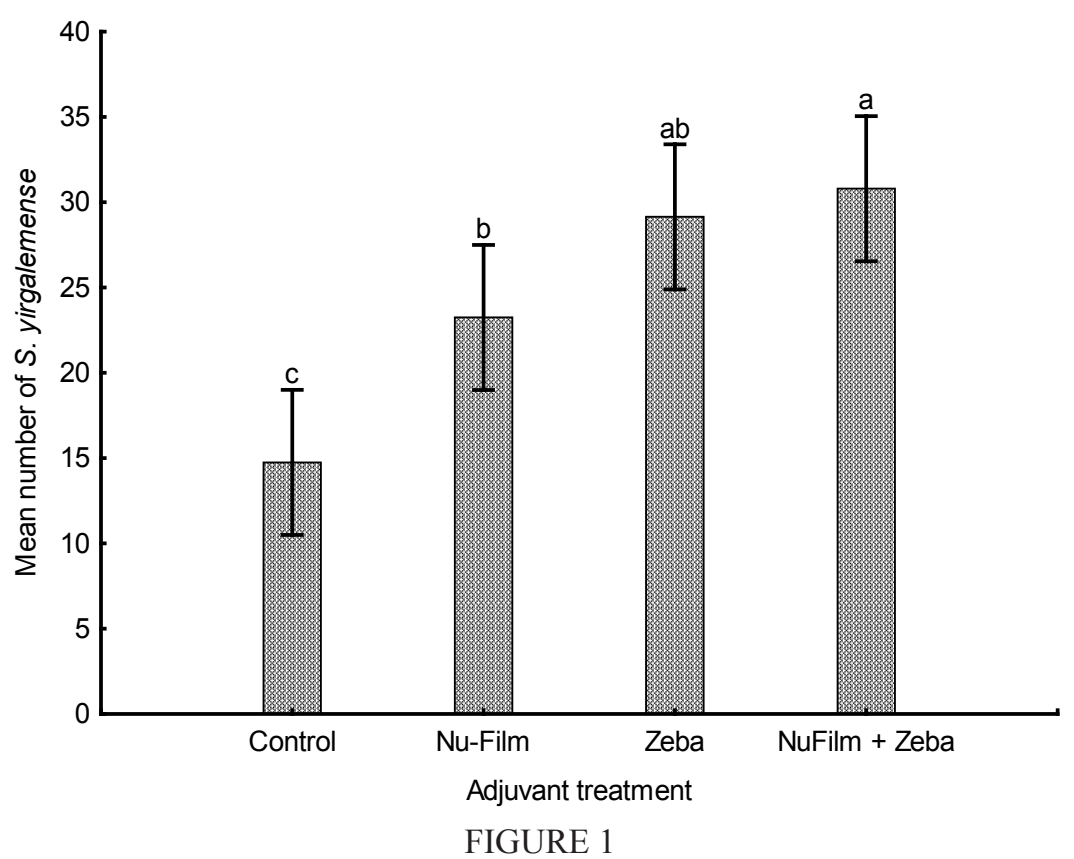

Mean percentage (95\% confidence interval) deposition of Steinernema yirgalemense infective juveniles (IJs) onto grapevine leaves, applied with a handheld sprayer at a concentration of $1000 \mathrm{IJs} / \mathrm{ml}$. After rinsing the leaves with tap water, the nematodes in the runoff were counted (one-way ANOVA: $\mathrm{F}_{(3.76)}=11.548, \mathrm{p}=<0.01$ ). Means of bars sharing a letter are not significantly different from one another.

241.52, $\mathrm{p}=<0.01)$. The combination of $\mathrm{Zeba}^{\circledR}$ and $\mathrm{Nu}-$ Film- $\mathrm{P}^{\circledR}$ was found to be the most effective $(84 \% \pm 5 \%$ mortality). The aforementioned combination was followed by $\mathrm{Zeba}^{\circledR}$ alone $(47 \% \pm 3 \%)$, and then by the nematodes alone $(26 \% \pm 2 \%)$, compared to the water control $(9 \% \pm 2 \%)$ (Fig. 2).

\section{Greenhouse bioassay}

The analysis of the results for mortality, after $48 \mathrm{~h}$, showed each treatment differed significantly from the others $(\mathrm{F}$ $\left.{ }_{20)}=207.42, \mathrm{p}=<0.01\right)$. The combination of $\mathrm{Zeba}^{\circledR}$ and Nu-Film-P ${ }^{\circledR}$ was the most effective $(88 \% \pm 3 \%$ mortality), followed by $\mathrm{Zeba}^{\circledR}$ alone $(56 \% \pm 5 \%)$, and then by the nematodes alone $(30 \% \pm 3 \%)$, compared with the water control $(13 \% \pm 2 \%)$ (Fig 3$)$.

\section{DISCUSSION}

Although P. ficus was found to be highly susceptible to EPNs in the laboratory bioassays (Le Vieux \& Malan, 2013; Platt et al., 2018), special challenges are encountered under aboveground environmental conditions, as soil is the natural habitat of EPNs. This study is a stepping-stone from very artificial conditions to less artificial conditions, with the next step being to move on to field trials. Lack of moisture/humidity is the most significant challenge. One option for overcoming the problem of humidity is the addition of adjuvants to the nematode suspension, assisting in the ability of nematodes to stick onto the leaves and prolonging the film of water on the leaves that is required for nematode movement.

The addition of $\mathrm{Zeba}^{\circledR}$ to EPN formulations resulted in significantly higher deposition of $S$. yirgalemense IJs, both alone and in combination with Nu-Film- $\mathrm{P}^{\circledR}$. The application of $\mathrm{Zeba}^{\circledR}$ and $\mathrm{Nu}-\mathrm{Film}-\mathrm{P}^{\circledR}$ gave significantly more IJs deposited than did Nu-Film- ${ }^{\circledR}$ alone, although all the treatments resulted in significantly higher deposition of S. yirgalemense IJs onto grapevines leaves than did water alone. The ability to double the number of IJs deposited onto grapevine leaves makes $\mathrm{Zeba}^{\circledR}$ (and, to a lesser extent, NuFilm- $\mathrm{P}^{\circledR}$ ) an attractive addition to suspensions for nematode application. The finding follows a similar trend to the research of Van Niekerk and Malan (2015), who assessed the use of Nu-Film-P ${ }^{\circledR}$ and Zeba ${ }^{\circledR}$ for the deposition of Heterorhabditis zealandica Poinar, 1990 onto citrus leaf discs. In that study, only the combination of Nu-Film- $\mathrm{P}^{\circledR}$ and Zeba ${ }^{\circledR}$ significantly increased the nematode deposition on citrus leaves compared to the control, due to the waxy (water-repellent) coating on the citrus leaves. This study indicates that $\mathrm{Zeba}^{\circledR}$ and NuFilm- ${ }^{\circledR}$ can effectively be used when targeting plants without waxy coatings, such as grapevine leaves.

The results of the growth chamber bioassay showed that $S$. yirgalemense was most effective when applied to female P. ficus in a combination of $\mathrm{Zeba}^{\circledR}$ and Nu-Film-P ${ }^{\circledR}$, with $84 \%$ mortality having been caused after $48 \mathrm{~h}$. The above indicates that, despite the fact that the addition of Nu-Film- $\mathrm{P}^{\circledR}$ did not significantly improve the deposition of nematodes onto grapevine leaves over the application of $\mathrm{Zeba}^{\circledR}$ alone, its status as a spreader and stick can still improve the control of $P$. ficus in formulation with S. yirgalemense. Van Niekerk and Malan (2015) performed a similar bioassay, assessing the mortality of $P$. citri, post-application of $H$. zealandica and $S$. yirgalemense in suspension with distilled water, xanthan gum or Zeba ${ }^{\circledR}$. They found that the addition of Zeba ${ }^{\circledR}$ caused a significant increase in the mortality of $P$. citri, improving the $H$. zealandica-induced mortality by $22 \%$ and the S. yirgalemense mortality by $27 \%$ at $80 \%$ relative humidity.

The greenhouse bioassay sought to assess the impact of 


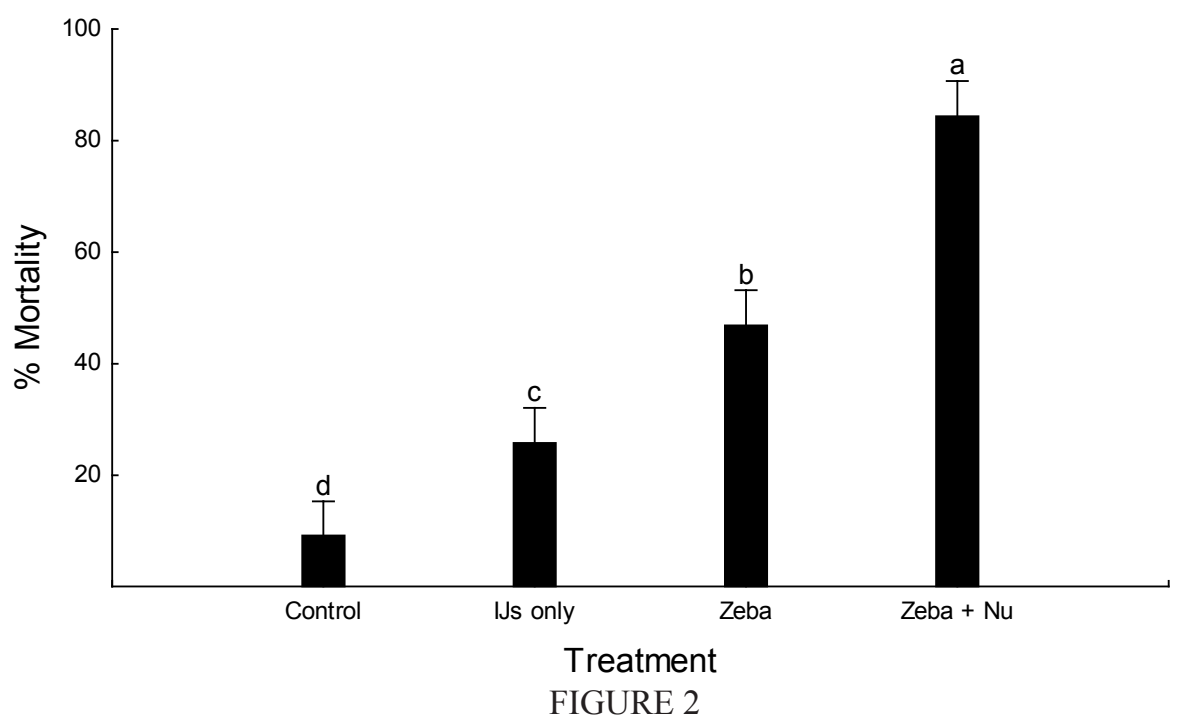

Mean percentage (95\% confidence interval) mortality of Planococcus ficus on grapevine leaves treated with Steinernema yirgalemense infective juveniles (IJs) after $48 \mathrm{~h}$ exposure in a glasshouse environment. IJs were applied to leaves with a handheld sprayer at a concentration of $3000 \mathrm{IJs} / \mathrm{ml}$ (one-way ANOVA: $\mathrm{F}_{(3,120)}=241.52 ; \mathrm{p}=<0.01$ ). Means of bars sharing a letter are not significantly different from one another.

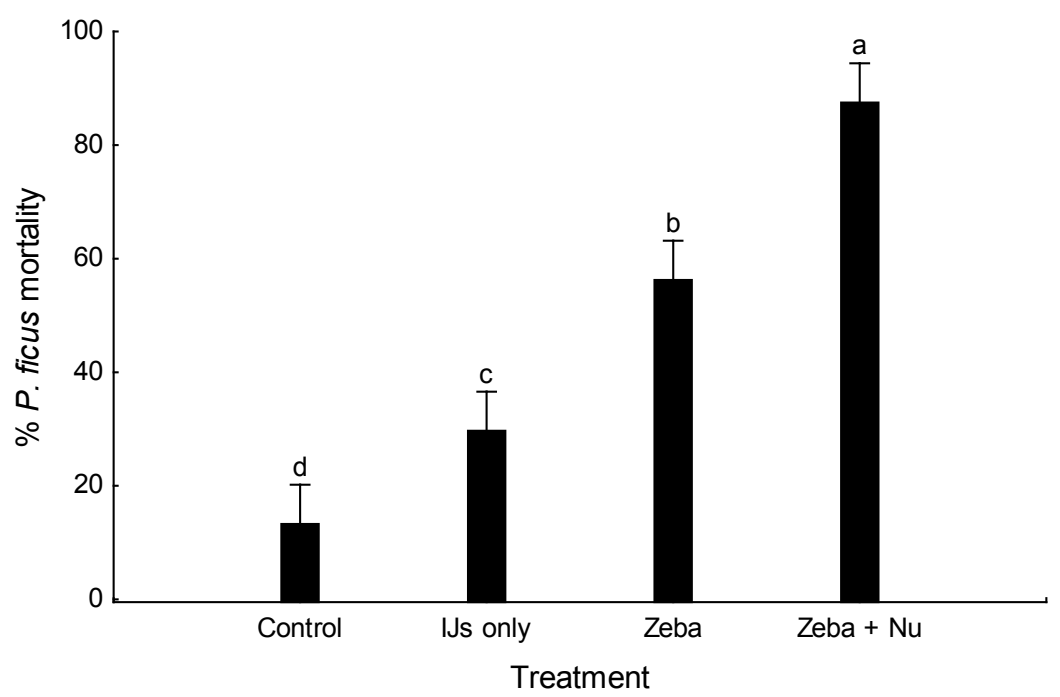

FIGURE 3

Mean percentage (95\% confidence interval) mortality of Planococcus ficus on grapevine leaves kept in a greenhouse environment, post-treatment with Steinernema yirgalemense. Infective juveniles (IJs) were applied to leaves with a handheld sprayer at a concentration of $3000 \mathrm{IJs} / \mathrm{ml}$. Means of bars sharing a letter are not significantly different from one another.

a less-controlled environment on treatments from the growth chamber bioassay. However, unlike the growth chamber bioassay, the average temperature and humidity were much lower over the course of the experiment - closer to conditions that would be expected in the field. Interestingly, these conditions did not appear to lower the overall P. ficus mortality, following the trend set by the growth chamber bioassay, in which the most effective treatment was also that of the combination of Zeba ${ }^{\circledR}$ with the IJ. The mortality of the control mealybugs was higher in the greenhouse bioassay than it was in the growth chamber bioassay, although only by $4 \%$, making this a promising indication that $\mathrm{Zeba}^{\circledR}$ and
Nu-Film- ${ }^{\circledR}$ can be used in conjunction to control $P$. ficus on grapevines under sheltered, or covered, conditions. The results are mirrored by the findings of Van Niekerk (2012), who emulated greenhouse conditions by performing a growth chamber bioassay at $22^{\circ} \mathrm{C}$ and $75 \pm 8 \% \mathrm{RH}$. However, the authors found that the addition of the both adjuvants, Zeba ${ }^{\circledR}$ and $\mathrm{Nu}-\mathrm{Film}-\mathrm{P}^{\circledR}$, to $S$. yirgalemense resulted in higher mortality in $P$. citri.

In conclusion, the results obtained indicate the potential for $S$. yirgalemense to be used to control $P$. ficus on foliage under controlled conditions, which is a key step in developing methods to apply S. yirgalemense to P. ficus in the field. Zeba ${ }^{\circledR}$, 
a polysaccharide starch, improves nematode deposition and infectivity when compared to Nu-Film-P ${ }^{\circledR}$. The use of EPN suspensions containing Nu-Film- $\mathrm{P}^{\circledR}$ (a spreader and sticker) alone showed much lower improvement in P. ficus mortality when compared to the use of suspensions containing $\mathrm{Zeba}^{\circledR}$ alone. However, combinations of both adjuvants offered significantly higher mortality, indicating that both adjuvants work synergistically to promote EPN survival and infectivity on foliage. When assessing adjuvants for use in EPN suspensions going forward, attention must be paid to the qualities of each constituent and how they interact. In addition, the ability of suspensions of $S$. yirgalemense, Zeba ${ }^{\circledR}$ and Nu-Film- $\mathrm{P}^{\circledR}$ to achieve $88 \%$ mortality in P. ficus in the glasshouse warrants future research into the ability of $S$. yirgalemense to control other insect pests in indoor environments.

\section{LITERATURE CITED}

Agri-Intel, 2018. Label information database. http://www.agri-intel.com

Arthurs, S., Heinz, K.M. \& Prasifka, J.R., 2004. An analysis of using entomopathogenic nematodes against above-ground pests. Bull. Entomol. Res. 94, 297-306. doi:10.1079/BER2003309

Baur, M.E., Kaya, H.K., Gaugler, R. \& Tabashnik, B., 1997. Effects of adjuvants on entomopathogenic nematodes and efficacy against Plutella xylostella. Biocontr. Sci. Technol. 7, 513-525. doi:10.1080/09583159730587

Ben-Dov, Y., 1994. A systematic catalogue of the mealybugs of the world (Insecta: Homoptera: Coccoidea: Pseudococcidae and Putoidae) with data on geographical distribution, host plants, biology and economic importance. Intercept Ltd., Andover.

Berlinger, M.J., 1977. The Mediterranean vine mealybug and its natural enemies in southern Israel. Phytoparasitica 5, 3-14. doi:10.1007/ BF03179429

Bovey, R., Gartel, W., Hewitt, W.B., Martelli, G.P. \& Vuitennez, A., 1980. Maladies a Virus et Affections Similaires de la Vigne. Atlas en Couleurs des Symptoms. Editions Payot, Lausanne.

Campbell, J.F., Lewis, E.E., Stock, S.P., Nadler, S. \& Kaya, H.K., 2003. Evolution of host search strategies in entomopathogenic nematodes. J. Nematol. 35, 142-145.

Campos-Herrera, R., 2015. Nematode pathogenesis of insects and other pests: Ecology and applied technologies for sustainable plant and crop protection. Springer International Publishing, Cham.

Daane, K.M., Bentley, W.J., Walton, V.M., Millar, J.G., Ingels, C.A., Weber, E.A. \& Gispert, C., 2008. New controls investigated for vine mealybug. Calif. Agric. 60, 31-38. doi:10.3733/ca.v060n01p31

De Waal, J.Y., Malan, A.P. \& Addison, M.F., 2013. Effect of humidity and a superabsorbent polymer formulation on the efficacy of Heterorhabditis zealandica (Rhabditida: Heterorhabditidae) to control codling moth, Cydia pomonella (L.) (Lepidoptera: Tortricidae). Biocontr. Sci. Technol. 23, 6278. doi:10.1080/09583157.2012.736472

FAO (Food and Agriculture Organization of the United Nations), 2016. FAOSTAT [Online]: http://www.fao.org/faostat/en/\#data/QC [accessed 13 December 2016].

Gaugler, R. \& Boush, G.M., 1978. Effects of ultraviolet radiation and sunlight on the entomogenous nematode, Neoaplectana carpocapsae. J. Invert. Pathol. 32, 291-296. doi:10.1016/0022-2011(78)90191-X
Geiger, C.A. \& Daane, K.M., 2001. Seasonal movement and distribution of the grape mealybug (Homoptera: Pseudococcidae): Developing a sample program for San Joaquin Valley vineyards. J. Econ. Entomol. 94, 291-301. doi:10.1603/0022-0493-94.1.291

Glazer, 1992. Survival and efficacy of Steinernema carpocapsae in an exposed environment. Biocontr. Sci. Technol. 2, 101-107.

Grewal, P.S., Selvan, S. \& Gaugler, R., 1994. Thermal adaptation of entomopathogenic nematodes: Niche breadth for infection, establishment, and reproduction. J. Thermal Biol. 19, 245-253. doi:10.1016/03064565(94)90047-7

Griffin, C.T., Boemare, N.E. \& Lewis, E.E., 2005. Biology and behaviour. In: Grewal, P.S., Ehlers, R.U. \& Shapiro-Ilan, D.I. (eds). Nematodes as biocontrol agents. CAB International, Wallingford. pp. $47-64$.

Head, J., Lawrence, A.J. \& Walters, K.F.A., 2004. Efficacy of the entomopathogenic nematode, Steinernema feltiae, against Bemisia tabaci in relation to plant species. J. Appl. Entomol. 128, 543-547. doi:10.1111/ j.1439-0418.2004.00882.x

Hussaini, S.S., 2002. Entomopathogenic nematodes for the control of crop pests. In: Upadhyay, R.K. (ed). Advances in microbial control of insect pests. Kluwer Academic/Plenum, Dordrecht. pp. 265 - 296.

Kaya, H.K. \& Stock, S.P., 1997. Techniques in insect nematology. In: Lacey, L.A. (ed). Manual of techniques in insect pathology. Academic Press, UK pp. $281-324$.

Lello, E.R., Patel, M.N., Matthews, G.A. \& Wright, D.J., 1996. Application technology for entomopathogenic nematodes against foliar pests. Crop Prot. 15, 567-574. doi:10.1016/0261-2194(96)00026-9

Le Vieux, P.D. \& Malan, A.P., 2013. The potential use of entomopathogenic nematodes to control Planococcus ficus (Signoret) (Hemiptera: Pseudococcidae). S. Afr. J. Enol. Vitic. 34, 296-306.

Lewis, E.E., 2002. Behavioural ecology. In: Gaugler, R. (ed). Entomopathogenic nematology. CAB International, Wallingford. pp. 205 -223 .

Malan, A.P., Knoetze R. \& Moore, S.D., 2011. Isolation and identification of entomopathogenic nematodes from citrus orchards in South Africa and their biocontrol potential against false codling moth. J. Invert. Path. 108, 115-125. doi:10.1016/j.jip.2011.07.006

Mráček, Z., 2002. Use of entomoparasitic nematodes (EPANs) in biological control. In: Upadhyay, R.K. (ed). Advances in microbial control of insect pests. Springer Science + Business Media, New York. pp 235 - 264.

Millar, I.M., 2002. Mealybug genera (Hemiptera: Pseudococcidae) of South Africa: Identification and review. Afr. Entomol. 10, 185-233.

Platt, T., Stokwe, N.F. \& Malan, A.P., 2018. Potential of local entomopathogenic nematodes for control of the vine mealybug, Planococcus ficus. S. Afr. J. Enol. Vitic. (in press).

Shapiro-Ilan, D.I. \& Cottrell, T.E., 2006. Susceptibility of the lesser peach borer (Lepidoptera: Sesiidae) to entomopathogenic nematodes under laboratory conditions. Environ. Entomol. 35, 358-365. doi:10.1603/0046225X-35.2.358

Shapiro-Ilan, D.I., Cottrell, T.E., Mizell III, R.F. \& Horton, D.L., 2016. Efficacy of Steinernema carpocapsae plus fire gel applied as a single spray for the control of the lesser peach borer, Synanthedon pictipes. Biol. Contr. 94, 33-36. doi:10.1016/j.biocontrol.2015.12.006

Shapiro-Ilan, D.I., Cottrell, T.E., Mizell III, R.F., Horton, D.L., Behle, R.W. \& Dunlap, C.A., 2010. Efficacy of Steinernema carpocapsae for control of the lesser peachtree borer Synanthedon pictipes: Improved aboveground suppression with a novel gel application. Biol. Contr. 54, 2328. doi:10.1016/j.biocontrol.2009.11.009 
Smits, P.H., 1996. Post-application persistence of entomopathogenic nematodes. Biocontrol Sci. Techn. 6, 379-388.

South African Table Grape Industry (SATI), 2016. Statistics booklet. SATI, Paarl.

South African Wine Industry Information and Systems (SAWIS), 2015 Final Report - Macro-economic impact of the wine industry on the South African economy (Also with Reference to the Impacts on the Western Cape). SAWIS, Pretoria.

TIBCO Inc., 2017. STATISTICA (data analysis software system), version 13. http://statistica.io

Van Niekerk, S., 2012. The use of entomopathogenic nematodes to control citrus mealybug, Planococcus citri (Hemiptera: Pseudococcidae) on citrus in South Africa. Thesis, Stellenbosch University, Private Bag X1, 7602 Matieland (Stellenbosch), South Africa.

Van Niekerk, S. \& Malan, A.P., 2015. Adjuvants to improve aerial control of the citrus mealybug Planococcus citri (Hemiptera: Pseudococcidae) using entomopathogenic nematodes. J. Helminthol. 89, 189-195. doi:10.1017 S0022149X13000771
Walton, V.M., 2003. Development of an integrated pest management system for vine mealybug, Planococcus ficus (Signoret), in vineyards in the Western Cape Province, South Africa. Dissertation, Stellenbosch University, Private Bag X1, 7602 Matieland, South Africa.

Walton, V.M. \& Pringle, K.L., 2004. Vine mealybug, Planococcus ficus (Signoret) (Hemiptera: Pseudococcidae), a key pest in South African vineyards. A review. S. Afr. J. Enol. Vitic. 25, 54-62. doi:10.21548/25-22140

Walton, V.M., Daane, K.M. \& Pringle, K.L., 2004. Monitoring Planococcus ficus in South African vineyards with sex pheromone-baited traps. Crop Prot. 23, 1089-1096. doi:10.1016/j.cropro.2004.03.016

Wilson, M. \& Gaugler, R., 2004. Factors limiting short-term persistence of entomopathogenic nematodes. J. Appl. Entomol. 128, 250-253. doi:10.1111/ j.1439-0418.2004.00814.x

White, G., 1927. A method for obtaining infective nematode larvae from cultures. Science 66, 302-303. 